\title{
К ВОПРОСУ ОБ ОТВЕТСТВЕННОСТИ ЗА САМОВОЛЬНУЮ ПОСТРОЙКУ: ПРИЗНАНИЕ ПРАВА СОБСТВЕННОСТИ ИЛИ СНОС
}

\section{ON THE ISSUE OF RESPONSIBILITY \\ FOR UNAUTHORIZED CONSTRUCTION: \\ THE RECOGNITION OF THE RIGHT OF OWNERSHIP OR DEMOLITION}

\section{A. Gudkov \\ A. Krasilschikov V. Mishchenko}

Summary: The article deals with one of the current problems of civil law related to liability for unauthorized construction. The analysis of the latest changes in article 222 of the civil code of the Russian Federation. It is concluded that overcoming the interpretation of provisions of the article under review should be reflected in the actual practice of the Supreme Court of the Russian Federation, which at the same time would create conditions for the formation of uniform court practice.

Keywords: unauthorized construction, developer, real estate, demolition, recognition of ownership, responsibility for unauthorized construction.

\author{
Гудков Анатолий Иванович \\ К.ю.н., дочент, ВЮИ ФСИН России, \\ gudkovaniv@yandex.ru \\ Красильщиков Анатолий Владимирович \\ К.ю.н., дочент, ВЮИ ФСИН России \\ krasilschikov@inbox.ru \\ Мищенко Вячеслав Иванович \\ К.ф.н., дочент, ВЮИ ФСИН России, \\ vyacheslav-mischenko@mail.ru
}

Аннотация: В статье рассмотрена одна из актуальных проблем гражданского права, связанная с ответственностью за самовольную постройку. Проведен анализ последних изменений ст. 222 ГК РФ. Сделан вывод, что преодоление различного толкования положений рассматриваемой статьи должно найти отражение в актуальном обобщении судебной практики, что одновременно создало бы условия формирования единообразной судебной практики.

Ключевые слова: самовольная постройка, застройщик, объекты недвижимости, снос, признание права собственности, ответственность за самовольное строительство.

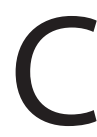

амовольное строительство - давнее и распространенное явление, сопряженное с множеством проблем для общества. Проблема самовольного строительства в России обусловлена многочисленными обстоятельствами. К объективным обстоятельствам относят быстрые темпы развития строительной отрасли, потребность в массовом строительстве объектов недвижимости, отсутствие концептуальных основ развития гражданского законодательства в сфере строительства [1]. Новеллы гражданского законодательства, регулирующие самовольное строительство, не разрешили накопившихся проблем, однако следует отметить, что в настоящее время на законодательном уровне расширены права самовольного застройщика [1].

Актуальность рассматриваемого вопроса связана как с ростом числа дел по применению соответствующих норм гражданского законодательства, так и с другими причинами, к примеру, в связи с вхождением в состав Российской Федерации новых территорий.

Основные критерии самовольной постройки закреплены в п. 1 ст. 222

ГК РФ. Общие последствия самовольного строительства закреплены в п. 2 ст. 222 ГК РФ. В частности, к ним относится невозможность приобретения права собственности на построенный объект недвижимости, а также снос таких построек.

Начиная с 2015 года, в гражданское законодательство вносятся изменения относительно режима самовольных построек. Меры по изменению законодательства направлены преимущественно на либерализацию данного института [3].

В новой редакции ст. 222 ГК РФ от 3 августа 2018 года предусмотрена альтернативная ответственность за самовольное строительство в виде приведения объекта в соответствие с законодательными требованиями.

Кроме этого, статья дополнена положением о минимальном и максимальном времени сноса самовольной постройки и приведения ее в соответствие с требованиями законодательства. Действовавшая ранее редакция рассматриваемой статьи давала возможность осуществлять снос самовольных построек в административном порядке практически без ограничений. Показательным в этом плане стал случай массового сноса торговых объектов в Москве в 2016 году, несмотря на подтвержденные факты зарегистрированных прав собственников данных объектов. Установленные в новой редакции ст. 222 ГК РФ ограничения позволяют избежать подобных ситуаций.

Важной новеллой ст. 222 ГК РФ становится новый 
субъект - добросовестный строитель самовольной постройки. Не является самовольным объект, созданный и в нарушение законодательства, если владелец земельного участка не знал или не мог знать о наличии ограничений в отношении данного земельного участка. Между тем названное положение вступает в противоречие с абз. 1 п. 1 ст. 222 ГК РФ и не дает гарантий для его реализации на практике.

В п. 3 ст. 222 ГК РФ содержатся положения, допускающие возможность установления права собственности на самовольную постройку. В том числе п. 3 ст. 222 ГК РФ устанавливает два пути легализации самовольной постройки: судебный порядок и иной порядок, установленный законом. Новая редакция ст. 222 ГК РФ упрощает процедуру легализации самовольной постройки. После законодательных изменений от 3 августа 2018 года, легализация возможна без разрешения на строительство и ввод объекта в эксплуатацию.

В соответствии с вновь введенными в 2018 году нормами, право собственности на самовольные постройки может быть признано при одновременном соблюдении условий:

- у лица, создавшего данную постройку, имелись права в отношении земли, допускающие строительство;

- сама постройка соответствует установленным требованиям;

- самовольная постройка не нарушает прав других лиц.

Неоднозначный подход законодателя к изложению правовых механизмов вступает в конфликт с реальным существом строительных процессов. Так, часть норм изложена слишком детально, другая не раскрыта вовсе, тем самым специфика регулируемой сферы отношений не отражена. Результатом этого может стать непродуктивная активность региональных и местных властей.

Согласно общему правилу, лицо, создавшее объект самовольного строительства, не приобретает на него право собственности. Это положение находит отражение в судебной практике в следующих случаях:

- при признании пристройки к многоквартирному дому самовольной у владельцев помещений не возникает право общей долевой собственности на конструктивные элементы здания, ставшие результатом самовольного строительства;

- объект самовольного строительства не может включаться в жилищный фонд и не может быть признан жилым помещением, что означает невозможность регистрации в таком помещении;

- объект самовольного строительства не может быть включен в наследственную массу;
- застройщик может требовать от правообладателя на земельный участок возмещения расходов в случае признания объекта строительства самовольным.

В отличие от вопроса признания права собственности на самовольные постройки, входящие в полномочия суда, принятие решения о сносе самовольных построек отводится, главным образом, органам местного самоуправления. В редакции ст. 222 ГК РФ от 1 сентября 2015 года органы местного самоуправления наделялись исключительным правом сноса в административном порядке объектов недвижимости, имевших признаки самовольных построек. В том числе это распространялось и на постройки с зарегистрированным правом собственности на них.

В соответствии с действующей редакцией п. 4 ст. 222 ГК РФ, субъекты, наделенные правом принимать решение о сносе самовольной постройки, могут воспользоваться данным правом только в трех случаях.

В первом случае решение о сносе принимается при отсутствии правоустанавливающих документов в отношении земельного участка.

Во втором случае это происходит, если самовольная постройка создается на участке, разрешенное использование которого противоречит такой постройке.

В третьем случае, кроме конфликта разрешенного пользования с видом постройки, постройка должна быть расположена в пределах зоны с особыми условиями использования.

Обновленное на основе законодательных новелл содержание института самовольной постройки имеет практические основания. Связано это с судебной практикой. В частности, способ защиты должен обеспечивать соответствие характеру допущенного нарушения. Суды при рассмотрении требований о сносе дают оценку соответствия избранного истцом способа защиты допущенному нарушению.

Для создания условий, обеспечивающих защиту прав субъектов строительства, законодатель включил иные правовые механизмы альтернативные сносу. Вновь введенные в законодательство механизмы легализации самовольной постройки позволяют сохранить созданный объект и включить его в гражданский оборот. Полномочиями о сносе объекта самовольного строительства обладают суд, а в некоторых случаях, как было отмечено ранее, органы местного самоуправления. Муниципальные администрации могут принять решение о сносе, если имеет место соответствия вышеназванным случаям. 
Новшества 2018 года затронули и сроки исполнения решения о сносе постройки. Так, законодатель установил минимальный срок сноса, составляющий три месяца и максимальный - 12 месяцев. При решении вопроса приведения рассматриваемых объектов в соответствие с надлежащими требованиями, учитывается характер постройки.

Подводя итог, можно отметить, что несмотря на периодические изменения законодательства о самовольной постройке, оно нуждается в дальнейшем совершенство- вании. Нормы гражданского законодательства, образующие институт самовольной постройки, характеризуются оценочностью и условным характером. Конкуренция с другими отраслями законодательства может повлечь противоречивую судебную практику. Преодоление различного толкования положений рассматриваемой статьи должно найти отражение в актуальном обобщении практики Верховного Суда Российской Федерации, что одновременно создало бы условия формирования единообразной судебной практики.

\section{ЛИТЕРАТУРА}

1. Бетхер В.А. Самовольное создание и изменение объектов недвижимости в Российской Федерации (гражданско-правовой аспект): монография / В.А. Бетхер. - М.: Юстицинформ, 2017. - 312 с.

2. Вдовина Н.Л., Кондратенко 3.К. Актуальные проблемы гражданско-правового режима самовольной постройки / Н.Д. Вдовина, З.К. Кондратенко // Марийский юридический вестник. - 2018. - № 1 (24). - С. 4-7.

3. Корнилова Н.В. Правовой режим самовольных построек в российском гражданском праве / Н.В. Корнилова // Вестник Хабаровского государственного университета экономики и права. - 2018. - № 4-5. - С. 24-32.

\footnotetext{
с Гудков Анатолий Иванович (gudkovaniv@yandex.ru), Красильщиков Анатолий Владимирович (krasilschikov@inbox.ru ), Мищенко Вячеслав Иванович (vyacheslav-mischenko@mail.ru).

Журнал «Современная наука: актуальные проблемы теории и практики»
}

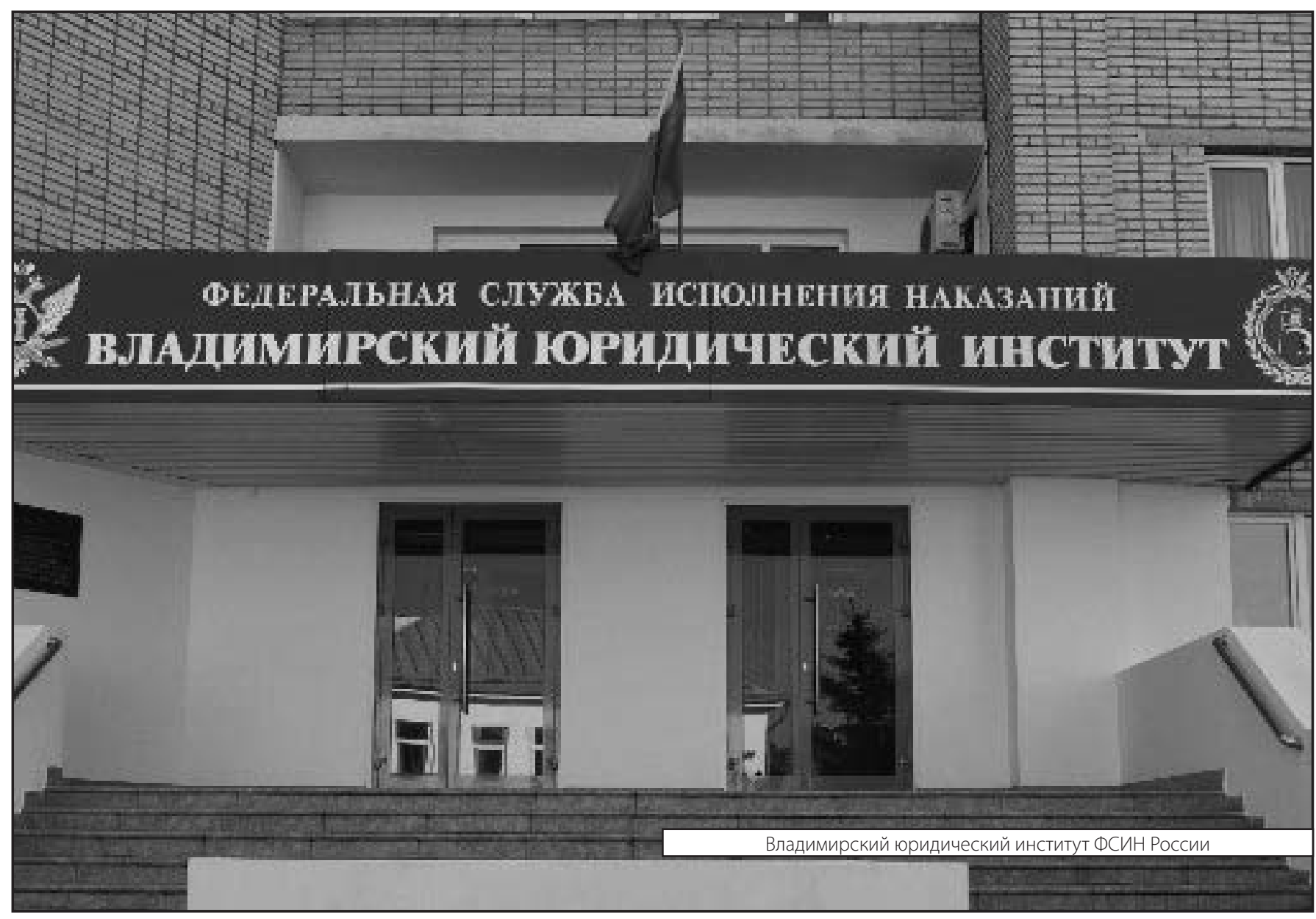

